\title{
DUCH MIŁOŚCI W NAUCZANIU KARDYNAŁA STEFANA WYSZYŃSKIEGO
}

\section{THE SPIRIT OF LOVE IN THE TEACHING OF CARDINAL STEFAN WYSZYŃSKI}

Cardinal Wyszyński continues teaching about the Holy Spirit as love and as a gift, which comes from the Bible and patristic tradition (eg St. Augustine). The basic text of his reflections on the God of Love are the words from the First Letter of St. John: "God is love" (1 Jn 4:8, 16). He reads these words, or the shortest definition of God, from the perspective of the Christian and his life experience. In the Holy Spirit, God communicates as love. To be gifted and loved by God means for man to elevate him to the supernatural order.

The Holy Spirit, who in the interior life of God is the Love of the Father and the Son, in his self-giving to the world (ad extra), pours God's love into human hearts (Rom 5: 5), enlivens and dynamises human life. Love as a proprium of the Holy Spirit is also the criterion of Christian identity and of the Church. Important threads of the discussed issue are also the spiritual motherhood of Mary and the establishment of her as the Temple and Bride of the Holy Spirit.

Key words: Holy Spirit, Third Person of the Holy Trinity, Love, supernatural order, Mary, Church, Wyszyński.

Do wydarzeń, które na trwałe wpisały się w pamięć kardynała Stefana Wyszyńskiego i do których będzie on często powracał, należy dzień „pasowania na rycerza Chrystusowego", czyli dzień bierzmowania. Sakrament bierzmowania otrzymał on z rąk bp. Antoniego Juliana Nowowiejskiego w parafii 
pw. Wniebowzięcia Najświętszej Maryi Panny w Andrzejewie w 1913 roku. Było to pierwsze świadome spotkanie dwunastoletniego gimnazjalisty z Duchem Świętym, o którym, po wielu latach, powie: „Pasowanie to przez wielorakie dary Ducha Świętego wywiera potężny wpływ na późniejsze życie chrześcijanina. Kto wie, może właśnie wtedy zrodziło się w mojej duszy powołanie kapłańskie, za którym kilka lat później poszedłem?"1. Od Ducha Swiętego bierzmowany otrzymuje różnorakie dary, ale również przez Niego jest uzdalniany, aby ich owocami dzielić się z innymi. W każdym czasie jest On dla człowieka „słodkim Gościem duszy", prawdziwym Przyjacielem².

Przez 57 lat swego kapłaństwa kardynał Wyszyński starał się być Bożym pasterzem i kochać wszystkich Bożą miłością nadprzyrodzoną3 . Jak mało kto był świadomy, że w życiu ludzkim wszystko „sprowadza się do miłości, do większego stopnia miłości” ${ }^{\prime}$. A choć miłość była dla niego cenną wartością, największą spośród cnót teologalnych czy niezastąpioną siłą, to jednak w pierwszej kolejności widział on w niej wielki dar, przenikającą go obecność Ducha Świętego, który jest Duchem Miłości.

Wielkim pragnieniem kardynała Wyszyńskiego było położenie dobrych fundamentów pod drugie tysiąclecie chrześcijaństwa w Polsce. Nie mogło zabraknąć wśród nich miłości ${ }^{5}$. Nie dziwi więc fakt, że z takim naciskiem Prymas Tysiąclecia kładł akcent na ostateczne zwycięstwo miłości - ogarniającą cały świat erę Ducha Miłości.

1 S. Wyszyński, Jasne promienie w obozie męki. O męczennikach w Działdowie, (Działdowo, 12.06.1967), [w:] tenże, „Idzie nowych ludzi plemię...”. Wybór przemówień i rozważan, Poznań-Warszawa 1973, s. 109.

2 Por. tenże, Kromka chleba, Warszawa 2001, s. 38.

3 Por. tenże, Dlaczego oddaję was wszystkich w dłonie Maryi. Wyjątki z kazań wygłoszonych w kościele Wszystkich Świętych (25 maja) i w Bazylice Najświętszego Serca Pana Jezusa (30 maja), (Warszawa, w maju 1961), [w:] tenże, Dzieła zebrane, t. VII, Warszawa 2008, [dalej skrót: DZ VII], s. 228-229.

4 Tenże, „A ponad wszystko - większa jest mitośc!...” (por. 1 Kor 13, 13). Na progu Wielkiego Postu, podczas dnia skupienia Instytutu Prymasowskiego, (Warszawa, 01.03.1960), [w:] tenże, Dzieła zebrane, t. VI, Warszawa 2007, [dalej skrót: DZ VI], s. 76.

5 Por. tenże, Pierwszy Apel Jasnogórski nowego Tysiąclecia: „Mandatum novum”,(Jasna Góra, 03.05.1966), [w:] tenże, „Idzie nowych..., s. 201; tenże, „Stare” $i$ „nowe” rzeczy na progu drugiego Tysiąclecia. (Trzebnica, 16.10.1966), [w:] tenże, „Idzie nowych..., s. 220; tenże, W nowe czasy - nowy cztowiek!, (Wrocław, 15.10.1966), [w:] tenże, „Idzie nowych..., s. 219. 


\section{Najwznioślejsze teologiczne określenie Boga}

Podczas, gdy pochwałę miłości głosi całe Pismo Święte, a Apostoł Paweł wychwala jej piękno ${ }^{6}$, to jednak nikt, tak jak Apostoł Jan - zdaniem kardynała Wyszyńskiego, nie zdołał ująć jej całościowo i bezpośrednio. Według znaczącego chrześcijańskiego agapetologa ${ }^{7} \mathrm{w}$ najpełniejszy sposób samą istotę wiary chrześcijańskiej wyrażają słowa z Pierwszego Listu św. Jana. „ «Bóg jest miłością» - powie Apostoł $(1 \mathrm{~J} \mathrm{4}, 8)$. Tak bowiem Bóg umiłował świat, że Syna swego Jednorodzonego dał, aby każdy, kto w Niego wierzy, nie zginął, ale miał życie wieczne» - wyjaśni Chrystus $(\mathrm{J} 3,16)$. Tak często głowimy się nad definicją bóstwa, a jest ona bardzo zwięzła i krótka: «Deus Caritas est» - «Bóg

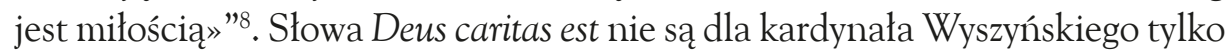
jednym z wielu biblijnych sformułowań, ale najbardziej treściwą definicją Boga, w nich bowiem zawiera się największa głębia Jego tajemnicy. Dzięki miłości, poprzez swoisty „łańcuch miłości” kardynał Wyszyński łączy z Bogiem - wielką, absolutną Miłością cały świat ${ }^{9}$.

\section{Duch Święty Miłością Ojca i Syna}

Znajdujące potwierdzenie w Biblii, a zwłaszcza u św. Jana podstawowe stwierdzenie, że Bóg jest istotową Miłością, prowadzi kardynała Wyszyńskiego w rozważaniach o Trójcy Świętej transcendentnej (ad intra), do rozumienia procesu pochodzenia Osób Bożych na zasadzie „udzielania się” Boga przez miłość ${ }^{10}$. „Faktem jest, że Bóg udziela się przez miłość. Pierwsze takie udzielenie dokonało się w Trójcy Świętej, gdy Bóg udzielił się swemu Synowi. Dał Mu swoją naturę, nie dzieląc jej ani mnożąc, lecz udzielając. Temu właśnie Bóg «zawdzięcza», że jest Ojcem. Kiedy się to stało. Przed początkiem, bez początku... [...]. W Synu udzielił się Bóg Duchowi Świętemu, który jest połączeniem Ojca i Syna. Stosunek między Ojcem i Synem wyraża się w miłości. To Duch Miłości! Jest to Miłość konieczna, dlatego że Ojciec nie może nie rodzić, nie byłby bowiem Ojcem. Skoro rodzi - jest Ojcem, ma Syna. [...] Jest Syn i jest

6 Por. tenże, „Abyście byli synami świattości...”. Przemówienie do naukowców, (Warszawa, 21.03.1959), [w:] tenże, Dzieła zebrane, t. V, Warszawa 2006 [dalej: DZ V], s. 117; tenże, Będziesz miłował!... Do lekarzy, (Warszawa, 21.09.1961), [w:] tenże, DZ VII, s. 437.

7 Por. Cz.S. Bartnik, Pedagogia narodowa Prymasa Stefana Wyszyńskiego, Lublin 2001, s. 243.

$8 \quad$ S. Wyszyński, Homo Dei - człowiek Boży. Brat dzieci Bożych, (Warszawa, 13.01.1974), [w:] tenże, Prymat człowieka w ladzie spotecznym, Londyn 1976, s. 207.

9 Por. tenże, Jesteśmy z miłości i dla mitości, [w:] tenże, Miłość na co dzień. Rozważania, cz. I, Rzym 1971, s. 24.

10 Por. J. Ewartowska, Boże Ojcostwo wewnętrzna zasada refleksji teologicznej Prymasa Stefana Wyszyńskiego, „Collectanea Theologica” 71 (2001) nr 4, s. 42. 
Ojciec, o którym Syn tak wiele mówił w Ewangelii. Ojciec i Syn tchną miłość w sposób konieczny. Ich stosunek jest miłością, bo Bóg to jest Miłość. Przez Ducha Świętego miłość ta rozlewa się szeroko" ${ }^{11}$. Na innym miejscu, jakby dopowie w odniesieniu do pochodzenia Ducha Świętego, że owo „udzielanie się” jest efektem „obcowania”. „Duch Święty to owoc obcowania wewnętrznego Ojca i Syna, owoc tej miłości i upodobania, która istnieje w Ojcu ku Synowi, w Synu ku Ojcu. «Ja i Ojciec jedno jesteśmy». Z tej przedziwnej jedności rodzi się Miłość. Bóg jest Miłością, a Miłość to Duch"12. W wewnątrztrynitarnym życiu Boga Ojciec i Syn „związani są wspólnym Duchem, który jest Ich Miłością, Świętym Tchnieniem, pochodzącym od Ojca i Syna”"13.

\section{Pełne miłości udzielanie się Trójjedynego Boga światu}

W rozważaniach o udzielaniu się Trójjedynego Boga światu albo też o Trójcy historiozbawczej (ad creaturam), kardynał Wyszyński mówi tak o ogólnym udzielaniu się Boga-Miłości światu, jak i to udzielanie się charakteryzuje w odniesieniu do poszczególnych Osób Bożych. W pierwszym znaczeniu koncentrującym się bardziej na naturze Boga powie ogólnie, że „Bóg-Miłość działa zgodnie ze swoją naturą, bo właściwością miłości i dobra jest udzielanie się"14. Ponieważ Bóg wiary chrześcijańskiej jest Bogiem Trójjedynym i tak też objawił się światu, dlatego kardynał Wyszyński odczytuje podstawowe wyznanie wiary chrześcijańskiej w perspektywie miłości. Wierzymy więc „w Ojca, który jest Stworzycielem naszym, który nas pragnął, chciał naszego istnienia, dał nam życie, i to przez miłość, bo nas umiłował. W Syna, który duszę swą dał za braci, a my wiemy, że «nie ma większej miłości nad tę, gdy ktoś duszę swoją daje za braci». I w Ducha Świętego, który jest Miłością Ojca i Syna, przez którego miłość Boża rozlana jest w sercach naszych. Spływa ona z naszych serc na całe otoczenie, na wszystkich, zgodnie z Chrystusowym przykazaniem: «Nowe

11 S. Wyszyński, „Patrzcie, jaka mitość dat nam Bóg...”, czyli humanistyczna postawa wobec świata $i$ samych siebie. Do Prymasowskiego Instytutu („Ósemki”) podczas rekolekcji w roku miłości i sprawiedliwości, (Warszawa, 12.09.1963), [w:] tenże, Dzieła zebrane, t. XI, Warszawa 2012 [dalej skrót: DZ XI], s. 170-171. Por. M. Parzyszek, Rodzina w nauczaniu kardynała Stefana Wyszyńskiego. Aspekt pedagogiczny, Lublin 2012, s. 129.

12 S. Wyszyński, Do gdańskiej młodzieży seminaryjnej. Kaplica seminaryjna, (Gdańsk-Oliwa, 13.04.1964), [w:] tenże, Dzieła zebrane, t. XII, Warszawa 2013 [dalej skrót: DZ XII], s. 340.

13 Tenże, Jesteśmy z mitości..., s. 23; tenże, Spojrzenie ku Trójcy Świętej. Po Mszy Świętej odprawionej przez Księdza Prymasa w uroczystość Trójcy Przenajświętszej, (Sosnowiec, 21.05.1967), [w:] tenże, Dzieła zebrane, t. XIX, Warszawa 2019 [dalej skrót: DZ XIX], s. 211-213.

14 Tenże, ,...A Abyśmy uwierzyli miłości...”, (Warszawa, 02.06.1972), [w:] tenże, „Idzie nowych..., s. 259 . 
przykazanie daję wam, abyście się społecznie miłowali» (J 13, 34), abyście miłowali jedni drugich" ${ }^{15}$. Udzielanie się Trójjedynego Boga jest zarazem obdarowaniem i obejmuje tak akt stworzenia, jak i przywrócenia do utraconego na skutek grzechu stanu przyjaźni z Bogiem poprzez całą ekonomię Zbawienia. Pośród wydarzeń zbawczych, zwłaszcza dzień Pięćdziesiątnicy oznacza nowy początek udzielania się Trójjedynego Boga w Duchu Świętym w Kościele, a poprzez Kościól całemu światu ${ }^{16}$. Na mocy niezgłębionej komunii trynitarnej, Duch Święty dopełni dzieła Syna rozpoczynając tym samym nową erę historii Zbawienia, która $z$ tej racji bywa także nazywana erą Ducha Miłości ${ }^{17}$.

Podczas gdy z jednej strony przez wielość symboli: woda, ogień, wiatr lub tchnienie, oliwa, gołębica, pieczęć, wino - Biblia, a zwłaszcza Nowy Testament stara się wypowiedzieć naturę, charakter i rolę Ducha Świętego, tak z drugiej strony jest On w Piśmie Świętym określony jako trzecia Osoba wiekuistego Boga. Kardynał Wyszyński mówi o osobowości i Boskości Ducha Świętego posługując się tak zaczerpniętymi z Nowego Testamentu tzw. formułami trynitarnymi, jak i stosując osobowe formy i określenia czy też wskazując na Jego osobowe czyny.

\section{Źródło porządku nadprzyrodzonego}

Mając doskonałe rozeznanie w porządku przyrodzonym kardynał Wyszyński baczną uwagę zwracał na porządek nadprzyrodzony ${ }^{18}$. W wiązaniu spraw ludzkich z Bożymi przyświecały mu w tym szczególnie zaczerpnięte z Orędzia Wielkanocnego słowa: „humanis divina iunguntur”"19. Tym jednak, co najbardziej wpływało na rozważania kardynała Wyszyńskiego o porządku nadprzyrodzonym jest prawda o Duchu Świętym, który jest Miłością, ale i Darem. Miłość, do jakiej już ze swej natury zdolny jest człowiek, a więc miłość naturalna, aby stać się miłością prawdziwie chrześcijańską musi być dopełniona

15 Tenże, Rozważania pod Krzyżem... Zakończenie rekolekcji wielkopostnych, (Warszawa, 03.04.1966), [w:] tenże, Dzieła zebrane, Warszawa 2016 [dalej skrót: DZ XVI], s. 416.

16 Por. Cz.S. Bartnik, Zarys myśli teologicznej kardynała Stefana Wyszyńskiego, „Ateneum Kapłańskie" 97 (1981), s. 224.

17 Por. S. Wyszyński, Naród potężnej wiary narodem spotęgowanej miłości, (Kielce, 17.07.1966), [w:] tenże, „Idzie nowych..., s. 206.

18 Por. R. Iwan, Polska chce żyć. Kardynała Stefana Wyszyńskiego wizja wspólnoty narodowo-państwowej, Augsburg-Toruń 2002, s. 16-19; J. Lewandowski, Pneumatologiczne aspekty „Cywilizacji mitości”, „Warmińskie Wiadomości Archidiecezjalne” 7 (1993), s. 138.

19 Por. S. Wyszyński, Humanizacja Boga, gdy Boże z ludzkim się sprzęga. Do biologów w Roku Życia, (Warszawa, 03.05.1959), [w:] tenże, DZ V, s. 194. 
miłością nadnaturalną czyli nadprzyrodzoną ${ }^{20}$. Bardzo wyraźnie w odniesieniu do porządku nadprzyrodzonego kardynał Wyszyński powie, że „Siłą, która nas utrzymuje w porządku nadprzyrodzonym, jest Duch Święty. Gdy w mojej duszy jest nieustanne doń wołanie: «Vieni, Sanctificator, omnipotens aeternae Deus» [Przyjdź, dawco świętości, Wszechmogący wiekuisty Boże...], to już jest dobrze, bo właśnie On tworzy we mnie porządek nadprzyrodzony, ten porządek nieskończony i niestworzony; ten porządek, który skłania do tego, że jestem obywatelem, że jestem dziedzicem najbardziej trwałej, niezniszczalnej społeczności, nad którą mogą się przewalać wszystkie burze dziejowe, przez którą mogą przejść wszystkie tanki, wszystkie bomby mogą być w niej wymiotane, ale tej więzi nic, żadna siła nie rozwali, nie rozerwie. Bo to ostatecznie zależy tylko od mojej słabości, którą na szczęście skutecznie - we mnie nawet - zwalcza Boża miłość" ${ }^{21}$. Porządek nadprzyrodzony jest w swej istocie osobową obecnością Boga w człowieku, która umożliwia mu współudział w wewnętrznym życiu Boga. Miłość jest szczególnym tworzywem nadprzyrodzonych relacji z Bogiem, gdyż obecność nadprzyrodzona Boga w człowieku jako obecność obdarowująca osobistym życiem Boga jest obdarowywaniem miłością. Więź nadprzyrodzona i nadprzyrodzona miłość winny się stale pogłębiaćc2

\section{Nieustanna aktualność Pięćdziesiątnicy}

Opisane przez św. Łukasza w Dziejach Apostolskich wydarzenie Pięćdziesiątnicy $(2,1-13)$ nie jest tylko faktem historycznym, ale w pełni tego słowa misterium, które celebruje się nie tylko w dniu ustanowionej uroczystości, ale w każdym czasie. Pięćdziesiątnica w całej swej nowości oznacza nieustanne udzielanie się Ducha Świętego ludziom oraz w nich zamieszkiwanie. W swej istocie „uroczystość Zesłania Ducha Świętego jest nie tylko pamiątką tego, co było ongiś w Wieczerniku, gdy Duch Święty zstąpił na Apostołów, zebranych razem z Maryją i niewiastami, ale jest świętem zawsze aktualnym. Czcimy w nim

$20 \quad$ Por. R. Iwan, Polska chce..., s. 40; R. Nęcek, Państwo w nauczaniu społecznym Prymasa Polski Stefana Wyszyńskiego. Studium teologiczno-moralne, Kraków 2004, s. 119.

21 S. Wyszyński, Zjednoczenie nasze nadal trwa. Do inteligencji katolickiej grupy „Odrodzenie”. Konferencja I, (Jasna Góra, 12.10.1957), [w:] tenże, Dzieła zebrane, t. III, Warszawa 1999 [dalej skrót: DZ III], s. 476. Por. M. Ozorowski, Kościót jako wspólnota w nauczaniu Prymasa Stefana Kardynała Wyszyńskiego, „Studia Prymasowskie UKSW”1 (2007), s. 247.

22 Por. tenże, Przemówienie imieninowe dla przetożonych zakonów żeńskich, (Warszawa, 03.08.1963), [w:] tenże, DZ XI, s. 36. 
bowiem to, co nieustannie staje się w Kościele i co nie może się nie stawać, ponieważ jest wyrazem obecności wśród nas mocy Boga, który jest miłością"23.

Zdumiewa z jak wielką precyzją i kunsztem kardynał Wyszyński stara się odmalować scenę Zesłania Ducha Świętego na Apostołów. Podobnie jak św. Łukasz koncentruje się on w pierwszej kolejności na obrazie wichru i ognia. „Dzieje się to w sposób bardzo delikatny. Wprawdzie: «nagle spadł z nieba szum, jakby uderzenie gwałtownego wichru i napełnił dom, w którym przebywali» $(\mathrm{Dz} 2,2)$, a jednak spoczął na nich spokojnie w postaci płomiennych, ogrzewających ogni. Jak ogień, który miłośnie obejmuje wszystko, co ma ogrzać, tak płomienie Ducha Świętego delikatnie objęły i przeniknęły do głębi serc Apostołów. Dopiero wtedy stali się zdolni, aby iść na wszystek świat i przepowiadać wszelkiemu stworzeniu, że Bóg jest Miłością"24. Przemiana, jakiej w Apostołach dokonał Duch Święty nie była tylko częściowa czy sferyczna, ale gruntowna i całościowa. To Duch Święty uzdolnił Apostołów, aby się stali „narzędziami” miłości. Tak w przypadku miłości apostolskiej kapłanów i biskupów, jak i miłości rodzicielskiej matki i ojca - najważniejsze jest służenie i przekazywanie miłości „czyli oddawanie i przekazywanie tego, co Bóg w nich umieścił dla innych”25.

\section{Dynamizm Bożej miłości}

Chyba najczęściej cytowanym i komentowanym tekstem przez kardynała Wyszyńskiego ukazującym dynamiczny charakter miłości Bożej są słowa z Listu do Rzymian: „Miłość Boża rozlana jest w sercach naszych przez Ducha Świętego" $(5,5)^{26}$. Ta Miłość, która pochodzi z łona Trójcy Świętej jest w swej

23 Tenże, „Miłość rozlana w sercach naszych”, [w:] tenże, Mitość na co dzień. Rozważania, cz. II, Rzym 1971, s. 47.

24 Tamże, s. 49. Por. tenże, Chwała Pani Jasnogórskiej w obliczu świata. Na konsekrację ołtarza w kościele Ojców Paulinów, (Warszawa, 12.02.1966), [w:] tenże, DZ XVI, s. 199. Zob. J. Hadryś, Miłość jako podstawa owocnego wypetniania misji ewangelizacyjnej w świetle nauczaniastugi Bożego Stefana kardynała Wyszyńskiego, „Ateneum Kapłańskie” 142 (2004) z. 1, s. 83 .

25 S. Wyszyński, „Mitość rozlana..., s. 50.

26 Por. tenże, Chrystus oczekuje od was pomocy. Do mężczyzn, (Warszawa, 13.04.1969), [w:] tenże, „Idzie nowych..., s. 294; tenże, Orędzie arcypasterskie na wielkopostna drogę do Boga Żywego, (Warszawa, 02.02.1953), [w:] tenże, Dzieła zebrane, t. I, Warszawa 1999, s. 217; tenże, „Pokój Wam!...”. Przemówienie powitalne Te Deum Zagłębia w Sosnowcu za Tysiąclecie Chrztu Polski i za 40 lat diecezji częstochowskiej, (Sosnowiec, 20.05.1967), [w:] tenże, DZ XIX, s. 207; tenże, Stużba zdrowia w stużbie mitości. Do lekarzy, (Warszawa, marzec 1968), [w:] tenże, „Idzie nowych..., s. 276-277; tenże, Spojrzenie ku..., s. 211-213; tenże, Stać nasz Naród na większa mitość. Zakończenie wizytacji kanonicznej parafii, (Pruszków, 28.05.1967), [w:] tenże, DZ XIX, s. 250. 
istocie rzeczywistością redempcyjną i zbawczą 27 . To Ona rozlewając się obejmuje swym zasięgiem czy też wprowadza człowieka na inny, tj. wyższy poziom egzystencji. „Duch Święty napełnia okrąg ziemi i daje tę miłość, przez którą z doczesności dźwigamy się w Bożą nieskończoność, w obcowanie bezpośrednie z Bogiem"28. Człowiek, w którym Duch Święty rozlewa miłość nie może jej zatrzymać tylko dla siebie. „Jeżeli miłość Boża rozlana jest w sercach naszych przez Ducha Świętego w nas mieszkającego, to z kolei miłość nasza, z Boga wzięta, ma się rozlewać w sercach innych ludzi przez tegoż Ducha Świętego w nas mieszkającego. I teraz możemy ocenić wartość życia, sens życia, piękność życia"29. Rozlewanie się miłości, będące dziełem Ducha Świętego nie jest niszczeniem, ale ożywianiem i poszerzaniem się ciągłym, dzięki również współudziałowi człowieka, jej kręgu.

\section{Maryja zawierzyła Miłości}

Choć pełnia objawienia się Ducha Świętego miała miejsce dopiero w dniu Pięćdziesiątnicy, to jednak już na progu Nowego Testamentu jest o Nim mowa w dialogu Archanioła Gabriela z Maryją (por. Łk 1,35). Kardynał Wyszyński z podziwem kontempluje dynamikę rozmowy, a zwłaszcza zachowanie się Maryi w momencie Zwiastowania w Nazarecie. „Na pytanie: «Jakże się to stanie...?» otrzymała przecież odpowiedź: «Duch Święty zstąpi na Ciebie...». To Jej wystarczy! Ona wie, że Duch Święty to Miłość, a dla Miłości nie ma rzeczy niemożliwej. Maryja uwierzyła więc w «niemożliwe», bo zawierzyła Miłości. W nagrodę usłyszała zaraz słowa Anioła: «[...] bo nie masz nic niemożliwego u Boga» (Łk 1, 38)"30. Ufna wiara Maryi jest naprawdę niezwykła i choć w rzeczywistości jest to zaledwie jej początek, to jednak ma on decydujące znaczenie dla całej historii wszechświata. Dla uwydatnienia niezwykłości postawy Maryi, kardynał Wyszyński zestawią ją z postawą pierwszej kobiety. „Ewa zwątpiła w Miłość, Maryja zawierzyła i skazała się na Miłość... Dlatego do dziś dnia dźwięczy w ludzkości Jej «fiat», chociaż było powiedziane tak cicho, ale i tak wyraźnie jak słowo kapłana podczas konsekracji, rodzące Boga-Człowieka na ołtarzach świata... «Fiat» Dziewicy, to nic innego, jak tylko zawierzenie, zgoda

27 Por. Cz. Bartnik, Pedagogia narodowa..., s. 54.

28 S. Wyszyński, „Stowa żywota Ty masz!”. Na rozpoczęcie Kongregacji Księży Dziekanów Archidiecezji Warszawskiej, (Warszawa, 18.09.1963), [w:] tenże, DZ XI, s. 195.

29 Tenże, Przemówienie do sióstr sług Jezusa. Z okazji setnej rocznicy urodzin matki Jadwigi Kiebuzińskiej, (Otwock, 29.08.1963), [w:] tenże, DZ XI, s. 113.

30 Tenże, Ta, która zawierzyła... Stużebnica Pańska skazana na mitość i stużbę ludowi Bożemu. Do Instytutu Prymasowskiego w dniu Zwiastowania, (Warszawa, 25.03.1960), [w:] tenże, DZ VI, s. 93. 
i aprobata miłości”31. Maryja będąc otwarta na Boga, stała się przestrzenią działania całej Trójcy Świętej. Poprzez Wcielenie Syna Bożego Maryja została wszczepiona w tajemnicę Trójcy Świętej. „Działa w Niej cała Trójca Święta, w sposób szczególny. Działał w Niej Ojciec, by dać przez Nią światu Syna Człowieczego, posłanego dla nas i dla naszego zbawienia. Działał w Niej Duch Święty, mocą którego poczęła Syna Bożego"32. Kardynał Wyszyński kładzie duży nacisk na szczególną więź i spokrewnienie Maryi z całą Trójcą Świętą w momencie Zwiastowania, a wyjątkową rolę Ducha Świętego w tym wydarzeniu upatruje w uczynieniu Jej Świątynią Boga ${ }^{33}$. Całkowita uległość Maryi wobec Boga, a zwłaszcza Ducha Świętego sprawiła, iż stała się Ona prawdziwą Oblubienicą Ducha Świętego ${ }^{34}$.

Śmierć Jezusa Chrystusa na krzyżu, a zwłaszcza Chrystusowy testament z krzyża (J 19, 25-27) uwidacznia wyraźnie temat szczególnie drogi kardynałowi Wyszyńskiemu, jakim jest duchowe macierzyństwo Maryi, realizowane w mocy Ducha Świętego w Kościele ${ }^{35}$. Czy Maryja tak ściśle związana z Duchem Świętym mogła zachować to bogactwo tylko dla siebie? Kardynał Wyszyński nie ma wątpliwość, że tak jak kiedyś Maryja pospieszyła do swej krewnej Elżbiety, tak w Wieczerniku antycypowała w pewnym sensie w tym, co miało nastąpić. „Tylko Ona wiedziała, kim jest Duch Święty. Chrystus wiele o Duchu Świętym nie mówił. W czasie trwania w Wieczerniku na modlitwie Maryja na pewno pouczyła Apostołów, kim jest Duch Święty, jak działa, jak działał w niej, jak zrozumiała tajemnicę Jego działania i jak ono było w Niej skuteczne" ${ }^{\text {"6 }}$. Ta komunia Maryi z Duchem Świętym była nie tylko przykładem, ale i świadectwem.

31 Tamże, s. 100.

32 Tenże, Co dzień ku lepszemu! Przemówienie do Ogólnopolskiej Pielgrzymki Akademickiej, (Jasna Góra, 28.05.1961), [w:] tenże, DZ VII, s. 190.

33 Por. J. Pach, Komunia życia Maryi z Trójca Święta w nauczaniu Stefana kardynała Wyszyńskiego, [w:] Trójca Święta a Maryja. Materiały z sympozjum mariologicznego zorganizowanego przez Polskie Towarzystwo Mariologiczne. Częstochowa, 6-8 września 1999 roku, (red.) T. Siudy, K. Pek, Częstochowa 2000, s. 399.

34 Por. S. Wyszyński, Chwała Pani..., s. 204.

35 Por. J. Pach, Komunia życia..., s. 401-402; I. Stolarczyk, Miłość jako zasada etyczno-społeczna w listach pasterskich Prymasa Tysiaclecia, [w:] Spoleczna potrzeba pamięci. Osoba idzieło Kardynała Stefana Wyszyńskiego Prymasa Tysiaclecia, (red.) A. Rynio, M. Parzyszek, Lublin 2017, s. 143.

36 S. Wyszyński, Kościótludu Bożego. „Nadprzyrodzona organizacja miłości”, [w:] tenże, Miłość na..., cz. II, s. 99. 


\section{Miłość Ducha Świętego wypełniająca Kościół}

Związek Ducha Świętego z Kościołem jest dla Kościoła konstytutywny i niezastąpiony, co uwidoczniło się już u jego początków, w momencie zstąpienia Ducha Świętego na zgromadzonych wraz „z niewiastami, z Maryją, Matką Jezusa, i z braćmi Jego" (Dz 1, 14). Kardynał Wyszyński bardzo mocno podkreśla, że „wspomnienie historyczne Zesłania Ducha Świętego jest w Kościele Bożym ciągle aktualne. Kościół «usechłby», gdyby miłość rozlana w sercach naszych przez Ducha Świętego przestała w nim istnieć. Kościół żyje z pokolenia na pokolenie, $z$ wieku na wiek, dzięki obecnej w nim Miłości Ducha Świętego, która udziela się wszystkim, napełniającym Dom Boży"37. Żywa obecność Ducha Świętego w Kościele sprawia, że jest on świątynią Ducha Świętego ${ }^{38}$.

Duch Święty jest w Kościele kontynuatorem misji Chrystusa ${ }^{39}$, a to odnosi się także do podstawowego prawa miłości zaszczepionego przez Chrystusa. „To Chrystus wszczepia we wspólżycie Kościoła, we wzajemne stosunki hierarchii i Ludu Bożego, podstawowe prawo swojej miłości, która jest jedna we wszystkich. To prawo miłości, wspólne dla wszystkich, staje się wewnętrzną miarą postępowania Kościoła i jego członków. To prawo jest całym światłem, całym życiem i spoiwem, gdyż wpisane jest ono w sercach naszych przez Ducha Miłości. Cały rozwój życia w Kościele, w jego Głowie i członkach, wrażliwość nasza na światła wewnętrzne, na bodźce laski, na mówiącego w sercach Ducha Świętego - to wszystko działa w ramach konstytucyjnego prawa miłości"40. Miłość czyni z Kościoła twierdzę niepokonaną dla mocy ciemności i zła. „Jeżeli Kościół ma na sobie znamię, że bramy piekielne nie zwyciężą go, to dlatego, że jego posłannictwem jest miłość, że miłość Boża rozlana jest w sercach waszych przez Ducha Świętego w Was mieszkującego; że Bóg jest miłością (por. $1 \mathrm{~J} 4,8$ ), a On nie umiera; że ludzie zawsze będą łaknąć ubożuchnej - jak kromka zeschłego chleba - miłości. I do niej się raczej zwrócą aniżeli do uczt nienawiści”"11. Trzeba, do czego szczególnie zdaje się zachęcać kardynał Wyszyński, aby drugim imieniem Kościoła była miłośćc ${ }^{42}$. Nieprzypadkowo więc

\footnotetext{
37 Tenże, „Miłość rozlana..., s. 55-56.

38 Por. M. Ozorowski, Kościót jako..., s. 246.

39 Por. Cz.S. Bartnik, Pedagogia narodowa..., s. 99.

40 S. Wyszyński, List do moich kaptanów, cz. II. Wspólnie z Kościołem, Paris 1969, s. 45. Por. Cz. Bartnik, Zarys myśli..., s. 225.

41 S. Wyszyński, Posłannictwem waszym jest mitość. Do neoprezbiterów w dniu święceń kapłańskich, (Gniezno, 11.06.1960), [w:] tenże, DZ VI, s. 230.

42 Por. tamże.
} 
często używanym określeniem Kościoła jest tytuł: „nadprzyrodzona organizacja miłości” ${ }^{\text {. Od }}$ Odnia Pięćdziesiątnicy, czyli od momentu zstąpienia Ducha Świętego na Kościół jest on nauczycielem najwyższego prawa miłości - Boga i człowieka ${ }^{44}$. Kardynał Wyszyński używa tu niekiedy w odniesieniu do Kościoła określenia: „katedra” lub „najwyższa uczelnia” miłości" ${ }^{45}$. Kościół nie tylko uczy o miłości, ale cały jest nią przeniknięty ${ }^{46}$.

Kościół w sposób szczególny poprzez czynności liturgiczne nieustannie trwa w wydarzeniu Pięćdziesiątnicy, które od samego początku nadało kształt i impuls jego misji. „Uroczystość Zielonych Świątek trwa przez wieki, przez okrągły rok, tydzień, godzinę, minutę, w każdym momencie, bo zawsze są ci, którym jest ona potrzebna, jak potrzebna jest miłość. Na tym polega nadprzyrodzony sens życia, pracy, istnienia i działania Kościoła Bożego na ziemi. «Spiritus Domini replevit orbem terrarum» - «Duch Święty napełnił okrąg ziemi. Alleluja». Radujmy się więc, alleluja!”47. Misją Kościoła na ziemi jest antycypowanie w tej komunii miłości, która w niebie ma swój ostateczny etap i pełnię.

\section{Charakterystyka miłości urzeczywistnianej w życiu chrześcijanina}

Z uwagi na nadprzyrodzony charakter miłości, przyjmuje ona w życiu chrześcijanina kształty, które zdecydowanie odbiegają od możliwości lub zdolności typowo ludzkich ${ }^{48}$. Kardynał Wyszyński mówi tu nawet o swoistym stylu życia ukształtowanym na wzór Boży. „Ponieważ miłość jest mocą Bożą i z Boga pochodzi, dlatego nabywa w człowieku coraz szlachetniejszych, Bożych wymiarów, właściwości, cech i przymiotów, tworząc swoisty styl życia. Jest to styl wielkiej delikatności i osobistego uciszenia. Nie słychać na ulicach głosu człowieka miłującego, jak ongiś niemal nie było słychać Chrystusa. Człowiek miłujący zawsze naśladuje Boga w tym, co najbardziej istotne"49. Choć milość wyraża się

43 Por. tenże, Humanistyczne wartości Bożego Narodzenia. Do uczennic szkół zakonnych podczas Opłatka, (Warszawa, 08.01.1962), [w:] tenże, Dzieła zebrane, t. VIII, Warszawa 2009, s. 36; tenże, Katolicki ideat wychowawczy. Do wychowawców i nauczycieli, (Jasna Góra, 19.04.1959), [w:] tenże, DZ V, s. 148; tenże, Wesel się, Jeruzalem... Rozważania na IV niedzielę Wielkiego Postu, (Warszawa, 20.03.1966), [w:] tenże, DZ XVI, s. 379.

44 Por. tenże, Przez wasza mękę - ku odrodzeniu życia ojczystego! Do stoczniowców (Warszawa, 07.06.1971), [w:] tenże, Prymat człowieka w ladzie społecznym, Londyn 1976, s. 35.

45 Por. tamże, s. 37.

46 Por. Cz. Bartnik, Pedagogia narodowa..., s. 107.

47 S. Wyszyński, „Mitość rozlana..., s. 56.

48 Por. J. Lewandowski, Pneumatologiczne aspekty..., s. 138.

49 S. Wyszyński, „Mitość rozlana..., s. 53. 
w czynie i wręcz rości sobie prawo do świadectwa ${ }^{50}$, to jednak człowiek Boży, a więc ten, który miłuje stara się być anonimowy, nie rzucać się w oczy, nie przypisywać sobie tytułu do uznania czy pochwały. W rzeczywistości bowiem „staje się on coraz bardziej niewidzialny, choć «wszędzie obecny». Jest czynny, ale bez krzyku i hałasu. Otoczenie przestaje wyczuwać osobę, dostrzega zaś jej czyny: wie, że był tu, chociaż jego śladów nie ma, nie widać! Był na pewno, bo pozostała miła atmosfera" ${ }^{51}$. W ten sposób rodzi się prawdziwy zachwyt miłością i jej wielkością, która czyniącemu ją każe zejść na bok, pójść dalej.

Inną ważną cechą miłości, na którą zwraca uwagę kardynał Wyszyński jest to, że winna ona być „dopasowana” do możliwości tych, którzy są nią objęci. Dla ukazania tej subtelności miłości kardynał Wyszyński posługuje się przykładem miłości matczynej. „Dostosuję się do Twojej miary jak matka, która daje niemowlęciu tyle pokarmu, ile ono przyjąć może. Dam ci nie tyle miłości, ile sam mam, lecz tyle, ile Ty zdolny jesteś przyjąć i pomieścić. A dam Ci w taki sposób, w jaki najlepiej możesz ją przyjąć" ${ }^{52}$. Tak, jak w Wieczerniku Apostołowie otrzymali od Ducha Świętego dar mówienia obcymi językami (por. Dz 2,4), aby każdy mógł usłyszeć o miłości na miarę swoich możliwości, tak również „nie możemy wchodzić w ludzkie życie z impetem, z pewnością własnej doskonałości i darów, jakie posiadamy. Mamy podchodzić do ludzi dyskretnie, jak Bóg przychodzi do naszego serca, jak Duch Święty na nas «osiada» i nas przepełnia. Dzieje się to w największej ciszy..." ${ }^{53}$. Miłości, choćby najdoskonalszej jej formy zewnętrznej nie da się komuś wtłoczyć lub narzucić na siłę. W miłości bowiem nie chodzi tylko o jej przejawy czy charakterystyczne formy, ale o ich znaczenie.

Jeszcze inną cechą miłości godną szczególnej uwagi jest jej powściągliwość i wyczucie. Kardynał Wyszyński mówi tu o jej dyskrecji i cichości. „Miłość jest dyskretna i niesłychanie cicha. Jest to jedna z najwłaściwszych jej cech. Im więcej człowiek ma miłości, tym bardziej cichnie, znika, tym mniej go widać i mniejsze są jego wymagania. Za to więcej myśli o tym, czego innym potrzeba. Przewiduje i uprzedza potrzeby ludzi” ${ }^{54}$. W przewidującej i uprzedzającej miłości ludzkiej współbrzmi i odzwierciedla się przewidująca i uprzedzająca miłość samego Boga.

\footnotetext{
50 Por. M. Parzyszek, Rodzina w nauczaniu..., s. 133.

51 S. Wyszyński, „Mitość rozlana..., s. 53-54.

52 Tamże, s. 54.

53 Tamże, s. 54-55.

54 Tamże, s. 55.
} 


\section{Zakończenie}

Choć w rozumieniu Ducha Świętego jako Miłości i jako Daru kardynał Wyszyński nie jest ani pionierem ani problematyka ta nie jest w jego kerygmatycznym nauczaniu dominująca, to jednak wydobywanie przez niego prawdy o Duchu Świętym z mroków tajemnicy jest niezwykle twórcze i życiowe. Jako wytrawny pasterz i pedagog nie zagłębia się on zbytnio ani w kwestie terminologiczne ani w rozważania teoretyczne, ale wychodząc $z$ analizy biblijnej pneumatologii, podobnie jak, zwłaszcza, św. Augustyn z Hippony, stara się wyciągać życiowe wnioski. Ostatecznie bowiem pnueuamatologia kardynała Wyszyńskiego jest głęboko przemyślaną antropologią, gdyż najlepiej Ducha Świętego widzi się w człowieku ukształtowanym przez Niego. Ten typowy dla kardynała Wyszyńskiego i budzący zaufanie sposób mówienia o Duchu Świętym wyrasta z jego głębokiego doświadczenia życia w Nim, z doświadczenia Kościoła.

Kardynał Wyszyński jako wybitny chrześcijański agapetolog był wyjątkowo zainteresowany udzielaniem się Boga Trójjedynego człowiekowi jako Miłość. To właśnie dzięki Duchowi Świętemu wewnętrzne życie Trójjedynego Boga, a więc wewnątrztrynitarna komunia miłości dotyka serca każdego człowieka i wynosi je do porządku nadprzyrodzonego. $Z$ wielką uwagą, ale i synowską miłością kontempluje kardynał Wyszyński duchowe macierzyństwo Maryi i widzi w Niej Świątynię i Oblubienicę Ducha Świętego. Myśl pneumatologiczna kardynała Wyszyńskiego ma wyraźny wydźwięk eklezjologiczny: pnueumatologia otwarta na eklezjologię i eklezjologia zakorzeniona w pneumatologii. Z Miłości pomiędzy Ojcem Niebieskim a Synem Bożym, uosobionej w Duchu Świętym rodzi się Kościól - „nadprzyrodzona organizacja miłości”. W Kościele wszystko zbudowane jest z miłości, miłość jest jego podstawowym tworzywem. Miłość nadprzyrodzona w całej swej niezwykłości i bogactwie nie niszczy czy też nie zastępuje miłości naturalnej, ale ją ożywia i uszlachetnia.

Słowa kluczowe: Duch Święty, Trzecia Osoba Trójcy Świętej, Miłość, porządek nadprzyrodzony, Maryja, Kościól, Wyszyński.

\section{Bibliografia:}

1. Bartnik Cz.S., Pedagogia narodowa Prymasa Stefana Wyszyńskiego, Lublin 2001.

2. Bartnik Cz.S., Zarys myśli teologicznej kardynała Stefana Wyszyńskiego, „Ateneum Kapłańskie" 97 (1981), s. 222-237.

3. Ewartowska J., Boże Ojcostwo wewnętrzna zasada refleksji teologicznej Prymasa Stefana Wyszyńskiego, „Collectanea Theologica” 71 (2001) nr 4, s. 39-57. 
4. Hadryś J., Miłość jako podstawa owocnego wypetniania misji ewangelizacyjnej w świetle nauczania stugi Bożego Stefana kardynała Wyszyńskiego, „Ateneum Kapłańskie” 142 (2004) z. 1, s. 81-95.

5. Iwan R., Polska chce żyć. Kardynała Stefana Wyszyńskiego wizja wspólnoty narodowo-państwowej, Augsburg-Toruń 2002.

6. Lewandowski J., Pneumatologiczne aspekty „Cywilizacji mitości”, „Warmińskie Wiadomości Archidiecezjalne" 7 (1993), s. 137-147.

7. Nęcek R., Państwo w nauczaniu społecznym Prymasa Polski Stefana Wyszyńskiego. Studium teologiczno-moralne, Kraków 2004.

8. Ozorowski M., Kościót jako wspólnota w nauczaniu Prymasa Stefana Kardynała Wyszyńskiego, „Studia Prymasowskie UKSW” 1 (2007), s. 241-250.

9. Pach J., Komunia życia Maryi z Trójca Święta w nauczaniu Stefana kardynała Wyszyńskiego, [w:] Trójca Święta a Maryja. Materiaty z sympozjum mariologicznego zorganizowanego przez Polskie Towarzystwo Mariologiczne. Częstochowa, 6-8 września 1999 roku, (red.) T. Siudy, K. Pek, Częstochowa 2000, s. 393-401.

10. Parzyszek M., Rodzina w nauczaniu kardynała Stefana Wyszyńskiego. Aspekt pedagogiczny, Lublin 2012.

11. Stolarczyk I., Miłość jako zasada etyczno-społeczna w listach pasterskich Prymasa Tysiaclecia, [w:] Społeczna potrzeba pamięci. Osoba i dzieło Kardynała Stefana Wyszyńskiego Prymasa Tysiaclecia, (red.) A. Rynio, M. Parzyszek, Lublin 2017, s. 135-147.

12. Wyszyński S., „A ponad wszystko - większa jest miłość!...” (por. 1 Kor 13, 13). Na progu Wielkiego Postu, podczas dnia skupienia Instytutu Prymasowskiego, (Warszawa, 01.03.1960), [w:] tenże, Dzieła zebrane, t. VI (1960), Warszawa 2007, s. 68-77.

13. Wyszyński S., „Abyście byli synami świattości...”. Przemówienie do naukowców, (Warszawa, 21.03.1959), [w:] tenże, Dzieła zebrane, t. V (1959), Warszawa 2006, s. 109-118.

14. Wyszyński S., „...Abyśmy uwierzyli miłości...”. (Warszawa, 02.06.1972), [w:] tenże, „Idzie nowych ludzi plemię...”. Wybór przemówień i rozważan, Poznań-Warszawa 1973, s. 259-269.

15. Wyszyński S., Będziesz mitował!... Do lekarzy, (Warszawa, 21.09.1961), [w:] tenże, Dzieła zebrane, t. VII (1961), Warszawa 2008, s. 436-439.

16. Wyszyński S., Chrystus oczekuje od was pomocy. Do mężczyzn, (Warszawa, 13.04.1969), [w:] tenże, „Idzie nowych ludzi plemię...”. Wybór przemówień i rozważan, Poznań-Warszawa 1973, s. 289-295.

17. Wyszyński S., Chwała Pani Jasnogórskiej w obliczu świata. Na konsekrację ołtarza w kościele Ojców Paulinów, (Warszawa, 12.02.1966), [w:] tenże, Dzieła zebrane, t. XVI (styczeń-kwiecień 1966), Warszawa 2016, s. 199-204.

18. Wyszyński S., Co dzień ku lepszemu! Przemówienie do Ogólnopolskiej Pielgrzymki Akademickiej, (Jasna Góra, 28.05.1961), [w:] tenże, Dzieła zebrane, t. VII (1961), Warszawa 2008, s. 183-202.

19. Wyszyński S., Dlaczego oddaję was wszystkich w dłonie Maryi. Wyjątki z kazań wygłoszonych w kościele Wszystkich Świętych (25 maja) i w Bazylice Najświętszego Serca Pana Jezusa (30 maja), (Warszawa, w maju 1961), [w:] tenże, Dzieła zebrane, t. VII (1961), Warszawa 2008, s. 224-230. 
20. Wyszyński S., Do gdańskiej młodzieży seminaryjnej. Kaplica seminaryjna, (Gdańsk-Oliwa, 13.04.1964), [w:] tenże, Dzieła zebrane, t. XII (styczeń-maj 1964), Warszawa 2013, s. 337-341.

21. Wyszyński S., Homo Dei - człowiek Boży. Brat dzieci Bożych, (Warszawa, 13.01.1974), [w:] tenże, Prymat człowieka w ladzie społecznym, Londyn 1976, s. 203-216.

22. Wyszyński S., Humanistyczne wartości Bożego Narodzenia. Do uczennic szkół zakonnych podczas Opłatka, (Warszawa, 08.01.1962), [w:] tenże, Dzieła zebrane, t. VIII (styczeń-lipiec 1962), Warszawa 2009, s. 34-38.

23. Wyszyński S., Humanizacja Boga, gdy Boże z ludzkim się sprzęga. Do biologów w Roku Życia, (Warszawa, 03.05.1959), [w:] tenże, Dzieła zebrane, t. V (1959), Warszawa 2006, s. 194-203.

24. Wyszyński S., Jasne promienie w obozie męki. O męczennikach w Działdowie, (Działdowo, 12.06.1967), [w:] tenże, „Idzie nowych ludzi plemię...”. Wybór przemówień i rozważań, Poznań-Warszawa 1973, s. 109-116.

25. Wyszyński S., Jesteśmy z miłości i dla miłości, [w:] tenże, Miłość na co dzień. Rozważania, cz. I, Rzym 1971, s. 21-30.

26. Wyszyński S., Katolicki ideat wychowawczy. Do wychowawców i nauczycieli, (Jasna Góra, 19.04.1959), [w:] tenże, Dzieła zebrane, t. V (1959), Warszawa 2006, s. 144-151.

27. Wyszyński S., Kościót ludu Bożego. „Nadprzyrodzona organizacja miłości”, [w:] tenże, Mitość na co dzień. Rozważania, cz. II, Rzym 971, s. 95-108.

28. Wyszyński S., Kromka chleba, Warszawa 2001.

29. Wyszyński S., List do moich kapłanów, cz. II. Wspólnie z Kościołem, Paris 1969.

30. Wyszyński S., „Mitość rozlana w sercach naszych”, [w:] tenże, Miłość na co dzień. Rozważania, cz. II, Rzym 1971, s. 47-56.

31. Wyszyński S., Naród potężnej wiary narodem spotęgowanej mitości, (Kielce, 17.07.1966), [w:] tenże, „Idzie nowych ludzi plemię...”. Wybór przemówień i rozważan, Poznań-Warszawa 1973, s. 205-207.

32. Wyszyński S., Orędzie arcypasterskie na wielkopostna drogę do Boga Żywego, (Warszawa, 02.02.1953), [w:] tenże, Dzieła zebrane, t. I (1949-1953), Warszawa 1991, s. 215-219.

33. Wyszyński S., „Patrzcie, jaka mitość dat nam Bóg...”, czyli humanistyczna postawa wobec świata $i$ samych siebie. Do Prymasowskiego Instytutu („Ósemki”) podczas rekolekcji w roku miłości i sprawiedliwości, (Warszawa, 12.09.1963), [w:] tenże, Dzieła zebrane, t. XI (lipiec-grudzień 1963), Warszawa 2012, s. 167-178.

34. Wyszyński S., Pierwszy Apel Jasnogórski nowego Tysiaclecia: „Mandatum novum”, (Jasna Góra, 03.05.1966), [w:] tenże, „Idzie nowych ludzi plemię...”. Wybór przemówień i rozważań, Poznań-Warszawa 1973, s. 201.

35. Wyszyński S., „Pokój Wam!...”. Przemówienie powitalne Te Deum Zagłębia w Sosnowcu za Tysiąclecie Chrztu Polski i za 40 lat diecezji częstochowskiej, (Sosnowiec, 20.05.1967), [w:] tenże, Dzieła zebrane, t. XIX (styczeń-lipiec 1967), Warszawa 2019, s. 207-211. 
36. Wyszyński S., Postannictwem waszym jest mitość. Do neoprezbiterów w dniu święceń kapłańskich, (Gniezno, 11.06.1960), [w:] tenże, Dzieła zebrane, t. VI (1960), Warszawa 2007, s. 228-231.

37. Wyszyński S., Przemówienie do sióstr stug Jezusa. Z okazji setnej rocznicy urodzin matki Jadwigi Kiebuzińskiej, (Otwock, 29.08.1963), [w:] tenże, Dzieła zebrane, t. XI (lipiec-grudzień 1963), Warszawa 2012, s. 110-114.

38. Wyszyński S., Przemówienie imieninowe dla przełożonych zakonów żeńskich, (Warszawa, 03.08.1963), [w:] tenże, Dzieła zebrane, t. XI (lipiec-grudzień 1963), Warszawa 2012, s. 33-38.

39. Wyszyński S., Przez wasza mękę - ku odrodzeniu życia ojczystego! Do stoczniowców (Warszawa, 07.06.1971), [w:] tenże, Prymat człowieka w tadzie społecznym, Londyn 1976, s. 31-37.

40. Wyszyński S., Rozważania pod Krzyżem... Zakończenie rekolekcji wielkopostnych, (Warszawa, 03.04.1966), [w:] tenże, Dzieła zebrane, t. XVI (styczeń-kwiecień 1966), Warszawa 2016, s. 412-421.

41. Wyszyński S., „Słowa żywota Ty masz!”. Na rozpoczęcie Kongregacji Księży Dziekanów Archidiecezji Warszawskiej, (Warszawa, 18.09.1963), [w:] tenże, Dzieła zebrane, t. XI (lipiec-grudzień 1963), Warszawa 2012, s. 195-201.

42. Wyszyński S., Stużba zdrowia w stużbie miłości. Do lekarzy, (Warszawa, marzec 1968), [w:] tenże, „Idzie nowych ludzi plemię...”. Wybór przemówień i rozważan, Poznań-Warszawa 1973, s. 273-278.

43. Wyszyński S., Spojrzenie ku Trójcy Świętej. Po Mszy Świętej odprawionej przez Księdza Prymasa w uroczystość Trójcy Przenajświętszej, (Sosnowiec, 21.05.1967), [w:] tenże, Dzieła zebrane, t. XIX (styczeń-lipiec 1967), Warszawa 2019, s. 211-213.

44. Wyszyński S., Stać nasz Naród na większa mitość. Zakończenie wizytacji kanonicznej parafii, (Pruszków, 28.05.1967), [w:] tenże, Dzieła zebrane, t. XIX (styczeń-lipiec 1967), Warszawa 2019, s. 250-255.

45. Wyszyński S., „Stare” $i$ „nowe” rzeczy na progu drugiego Tysiaclecia, (Trzebnica, 16.10.1966), [w:] tenże, „Idzie nowych ludzi plemię...”. Wybór przemówień i rozważań, Poznań-Warszawa 1973, s. 219-220.

46. Wyszyński S., Ta, która zawierzyła... Stużebnica Pańska skazana na mitość i stużbe ludowi Bożemu. Do Instytutu Prymasowskiego w dniu Zwiastowania, (Warszawa, 25.03.1960), [w:] tenże, Dzieła zebrane, t. VI (1960), Warszawa 2007, s. 92-100.

47. Wyszyński S., W nowe czasy - nowy człowiek!, (Wrocław, 15.10.1966), [w:] tenże, „Idzie nowych ludzi plemię...”. Wybór przemówień i rozważań, Poznań-Warszawa 1973, s. 219.

48. Wyszyński S., Wesel się, Jeruzalem... Rozważania na IV niedzielę Wielkiego Postu, (Warszawa, 20.03.1966), [w:] tenże, Dzieła zebrane, t. XVI (styczeń-kwiecień 1966), Warszawa 2016, s. 374-382.

49. Wyszyński S., Zjednoczenie nasze nadal trwa. Do inteligencji katolickiej grupy „Odrodzenie”. Konferencja I, (Jasna Góra, 12.10.1957), [w:] tenże, Dzieła zebrane, t. III (1956-1957), Warszawa 1999, s. 473-482. 